\title{
PENERAPAN E-GOVERNMENT DALAM PELAYANAN ADMINISTRASI KEPEGAWAIAN: STUDI DI BKPSDM KABUPATEN SUMENEP
}

\author{
Ida Syafriyani \\ Program Studi Administrasi Negara, Fakultas Ilmu Sosial Dan Ilmu Politik, Universitas Wiraraja Sumenep, \\ idafisipunija@gmail.com \\ Yuli Putri Zaituna \\ Program Studi Administrasi Negara, Fakultas Ilmu Sosial Dan Ilmu Politik, Universitas Wiraraja Sumenep
}

\begin{abstract}
Abstrak
Pemerintah Kabupaten Sumenep telah menerapkan E-Government dalam pelayanan administrasi kepegawaian, yang berupa pengelolaan sistem infomasi manajemen kepegawaian (SIMPEG) dengan menciptakan sistem pelayanan yang berbasis on line. SIMPEG diresmikan sejak tahun 2013 oleh Badan Kepegawaian dan Mengembangan Sumber Daya Manusia. Yang bertujuan untuk memudahkan dalam mengelola data pegawai. Permasalahan penelitian Bagaimanakah penerapan E-Government dalam pelayanan administrasi kepegawaian di badan kepegawaian dan pengembangan sumber daya manusia Kabupaten Sumenep. Tujuan penelitian untuk mengetahui penerapan E-Government dalam pelayanan administrasi kepegawaian di badan kepegawaian dan pengembangan sumber daya manusia Kabupaten Sumenep. Penelitian ini menggunakan metode pendekatan deskriptif kualitatif, yang menjadi fokus penelitian ini yaitu 1) E-Leadership, 2) infrastruktur jaringan informasi, 3) pengelolaan jaringan, dan 4) masyarakat dan sumber daya manusia. Subjek penelitian ini informan kunci, utama, dan pendukung, teknik pengumpulan data dengan wawancara, observasi, dan dokumentasi, dengan analisis data yaitu, reduksi data, display data, dan verifikasi data. Berdasarkan hasil penelitian menunjukkan bahwa secara garis besar penerapan E-Government yang berupa SIMPEG telah baik diterapkan. Didukung dengan E-Leadership, pengelolaan informasi serta infrastruktur jaringan informasi yang telah menyediakan seperti adanya Server dan Fitur optic yang berfungsi untuk menyimpan data dan menyediakan jaringan pengelolaan data kepegawaian. Akan tetapi terdapat kendala yang menghambat penerapan E-Government yaitu terletak pada pejabat pengelolaan data di tiap-tiap OPD yang masih kurang memahami teknologi informasi.
\end{abstract}

Kata Kunci: E-Government, pelayanan, dan kepegawaian

\begin{abstract}
Sumenep Government has implemented E-Government in staffing administration services, in the form of managing the staffing management information system (SIMPEG) by creating an online-based service system. SIMPEG was inaugurated since 2013 by the Human Resources and Human Resources Development Agency. The aims to make it easier to manage employee data. The problems is how the application of E-Government in the service of personnel administration in the human resources and human resource development agency of Sumenep Regency. The research objective is to determine the application of E-Government in the service of personnel administration in the human resources and human resource development of Sumenep. Analysis method uses a descriptive qualitative approach, which is the focus of this research are: 1) E-leadership, 2) information network infrastructure, 3) network management, and 4) community and human resources. The subjects of this study were key informants, main, and supporting informants, data collection techniques by interviewing, observing, and documenting, with data analysis namely, data reduction, data display, and data verification. Based on the results shows that in general the application of E-Government in the form of SIMPEG has been well applied. Supported by E-Leadership, information management and information network infrastructure that has provided such as the presence of optical servers and features that function to store data and provide a data management network for personnel. However, there are obstacles that hinder the implementation of E-Government, which lies in the data management officials in each OPD who still lack understanding of information technology.
\end{abstract}

Keywords: E-Government, service, and staffing.

\section{PENDAHULUAN}

Kehadiran birokrasi dalam mengatur sendi-sendi kehidupan warga Negara Indonesia telah mengalami proses yang panjang dalam perjalanan bangsa. Dimulai dari masa kerajaaan, penjajan, orde lama, orde baru, yang mana periode ini telah menggambarkan bahwa birokrasi tidaklah netral. Sehingga pemerintah melakukan 
pergeseran paragigma dengan melakukan reformasi birokrasi yang ditandai dengan posisi birokrasi sebagai pelayan publik atau masyarakat.

Reformasi birokrasi ditujukan untuk mendesain ulang birokrasi yang berada dilingkungan pemerintah kea rah yang lebih baik sesuai dengan kebutuhan kondisi saat ini. Dengan adanya reformasi birokrasi yakni mewujudkan tatakelola pemerintah yang baik, yaitu birokrasi yang bersih, bebas KKN, professional, efisien dan efektif, transparan dan akuntabel sehingga birokrasi pemerintahan mampu menghasilkan dan memberikan pelayanan public dengan prima.

Perkembangan teknologi, informasi dan komunikasi, dalam aktivitas kehidupan manusia dalam berbagai sektor tengah mengalami perubahan. Pemerintah memiliki kewajiban memberikan pelayanan publik yang merata keseluruh mayarakat. Salah satu kebijakan pemerintah dengan menerapkan E-Government. Pemerintah Indonesia sendiri telah mengeluarkan Instruksi Presiden Nomor 3 tahun 2003 tentang Kebijakan dan Strategi Nasional Pengembangan E-Government yang menginstruksikan kepada seluruh pejabat terkait, baik pemerintah pusat maupun pemerintah daerah untuk mengembangkan E-Government secara nasional. Penerapan E-Government mulai dari bentuk layanan yang sederhana yaitu penyediaan informasi dan data-data berbasis komputer tentang pelaksanaan dan penyelenggaraan pemerintahan dan pembangunan sebagai bentuk wujud keterbukaan (transparancy) dalam pelaksanaan pelayanan publik.

Salah satu OPD yang menerapkan E-Government di Kabupaten Sumenep yaitu di Badan Kepegawaian dan Pengembangan Sumber Daya Manusia. Kabupaten Sumenep memiliki 27 wilayah kecamatan dengan 18 berada didaratan sedangkan 9 berada dikepulauan dan Kabupaten Sumenep memiliki pulau terbanyak Sejawa Timur. Terdiri dari 126 pulau dengan rincian 48 pulau berpenghuni dan 78 sisanya merupakan pulau tak berpenghuni, (Bappeda Kabupaten Sumenep, 2015). Badan Kepegawaian dan Pengembangan Sumber Daya Manusia Kabupaten Sumenep melakukan inovasi dalam menerapkan E-Government untuk mewujudkan manajerial kepegawaian yang lebih cepat dan akurat terutama di daerah kepulauan.

Badan Kepegawaian dan Pengembangan Sumber Daya Manusia memiliki tugas pokok melaksanakan urusan Pemerintahan Daerah dalam penyusunan dan pelaksanaan kebijakan daerah bidang Kepegawaian, telah membuat dan mengembangkan website http://bkpsdm.sumenep.go.id. Masyarakat maupun pegawai dapat mengakses alamat website tersebut melalui beberapa fasilitas yang disediakan BKPSDM, salah satunya yaitu Sistem Informasi Manajemen Kepegawaian.
Sistem Informasi Manajemen Kepegawaian sangat penting dalam memberikan pelayanan kepada seluruh personalia yang ada, karena pegawai merupakan aset penting dalam penyelenggaraan organisasi yang perlu dikelola dengan baik. Pengelolaan pegawai yang baik dalam lingkup kecil akan meningkatkan kinerja pegawai dan dalam lingkup yang lebih besar serta akan membawa perbaikan kinerja pemerintah secara keseluruhan. Mengingat pentingnya pengelolaan data pegawai tersebut, maka peningkatan kualitas pengelolaan kepegawaian melalui penerapan Sistem Informasi Manajemen Kepegawaian merupakan salah satu prioritas dalam tahapan pengembangan E-Government.

Sistem Informasi Manajemen Kepegawaian yang diterapkan oleh BKPSDM Kabupaten Sumenep masih terdapat beberapa kendala dalam mewujudkan kebijakan E-Government. Menurut bapak sapta berpendapat bahwa dalam penerapan SIMPEG yang dilakukan Badan kepegawaian dan pengembangan sumber daya manusia masih ada kendala seperti minimnya pegawai yang mengelola SIMPEG di tiap-tiap instansi sehingga dalam hal ini perlu adanya pemberdayaan atau pelatihan yang dilakukan kepada operator yang ada di kabupaten sumenep agar lebih mudah saat melakukan pengaksesan serta fasilitas yang tidak merata di tiap-tiap Instansi yang ada di kabupaten sumenep.

Menghilangkan kesenjangan antara tiap OPD diperlukan peran pemerintah sehingga sistem yang dijalankan di daratan secara berkesinambungan juga dapat dijalankan dengan baik di daerah kepulauan. Untuk itu sistem kepegawaian yang dilakukan oleh BKPSDM perlu adanya sinergitas dan dukungan dari pemerintah, tidak terkecuali di daerah Kepulauan agar tercipta sistem yang berkesinambungan.

Berdasarkan uraian latar belakang yang sudah dijelaskan, timbul keinginan penulis untuk membahas dalam suatu karya ilmiah berbentuk Skripsi dengan judul "Penerapan E-Government dalam Pelayanan Administrasi Kepegawaian di Badan Kepegawaian dan Pengembangan Sumber Daya Manusia (BKPSDM) Kabupaten Sumenep".

Tujuan Penelitian ini Untuk mengetahui Penerapan Reformasi Birokrasi Melalui E-Government dalam Pelayanan Administrasi Kepegawaian di Badan Kepegawaian dan Pengembangan Sumber Daya Manusia (BKPSDM) Kabupaten Sumenep. Penelitian ini diharapkan dapat memberikan sumbangan pemikiran kepada pihak terkait dan sebagai referensi bagi pembaca secara umum maupun para praktisi akademik. 


\section{METODE}

Jenis penelitian ini yang digunakan adalah metode penelitian deskriptif dengan pendekatan kualitatif. Adapun yang menjadi fokus peneliti mengacu pada pendapat Kurniawan dalam hardiansyah (2011:117) tentang pemanfaatan teknologi informasi pada umumnya ditunjau dari sejumlah aspek yaitu E-Leadership, infrastruktur jaringan informasi, pengelolaan informasi dan masyarakat dan sumber daya manusia. Lokasi penelitian di Badan Kepegawaian Dan Pengembangan Sumber Daya Manusia Kabupaten Sumenep. Sumber data menurut sugiyono ada dua yaitu data primer diperoleh dari hasil penelitian di lapangan melalui wawancara dan data sekunder diperoleh dengan mencari dokumendokumen tentang aplikasi SIMPEG serta melakukan wawancara kepada setiap operator pengelolaan SIMPEG di setiap OPD.

Sementara, yang menjadi Subjek dan Objek peneliti adalah Kepala bidang data dan informasi kepegawaian sebagai informan kunci, kepala sub bidang data kepegawaian dan kepala sub bidang informasi kepegawaian sebagai informan utama, serta pegawai pengelola data pegawai di setiap OPD sebagai informan pendukung. Teknik pengumpulan data yang peneliti kumpulkan sesuai dengan pendapat Sugiyono (2011:169) yang terdiri dari Wawancara, Observasi dan Dokumentasi.

Teknik analisa data, yang dilakukan peneliti menurut Sugiyono (2011:246) terdapat tiga alur kegiatan yaitu: Reduksi Data, Penyajian Data dan Penarikan Kesimpulan. Terakhir Keabsahan Data dalam penelitian ini sesuai dengan (Sugiyono,2014:270-277) dengan meliputi Uji Validitas Internal (Credibility), Validitas Eksternal (Transferability), Realibilitas (Dependenbility) dan Obyektivitas (Confirmability).

\section{HASIL DAN PEMBAHASAN Gambaran Umum Objek Penelitian}

Badan Kepegawaian Dan Pengembangan Sumber Daya Manusia (BKPSDM) Kabupaten Sumenep sebagai Organisasi Perangkat Daerah yang mengemban tugas dalam menjamin kelancaran penyelenggaraan manajemen kepegawaian daerah. Dalam upayanya menyikapi isu-isu strategis serta tantangan perubahan dan perkembangan lingkungan eksternal yang terjadi, maka dipandang perlu untuk meningkatkan pelayanan dibidang kepegawaian khususnya terhadap Pegawai Negeri Sipil dilingkungan Pemerintah Kabupaten Sumenep. Disadari bahwa kualitas pelayanan publik sangat ditentukan oleh kemampuan dan profesionalisme penyelenggaranya yaitu Pegawai Negeri Sipil. Oleh karena itu, melalui pelayanan kepegawaian yang berkualitas terhadap PNS diharapkan akan memberikan motivasi untuk lebih meningkatkan pelayanan kepada masyarakat.

Tahun 2016 berdasar pada Peraturan Pemerintah Nomor 18 Tahun 2016 tentang Organisasi Perangkat Daerah dan Peraturan Daerah Kabupaten Sumenep Nomor 8 Tahun 2016 tentang Pembentukan dan susunan Perangkat Daerah. Sedangkan jabaran tugas dan fungsinya tertuang pada Peraturan Bupati Sumenep Nomor 64 Tahun 2016 tentang kedudukan, Susunan, Tugas Fungsi dan Tata kerja Badan Kepegawaian Daerah dan Pengembangan Sumber Daya Manusia Kabupaten Sumenep.

\section{E-Leadership}

Mengingat betapa kompleksnya pengembangan E-Government di lingkungan instansi pemerintah daerah diperlukan upaya pemanfaatan informasi dan teknologi. Hal ini selaras dengan yang dinyatakan oleh World Bank Group dalam Suaedi dan Wardiansyah (2010:54) bahwa E-Government merupakan sebagai upaya pemanfaatan informasi dan teknologi komunikasi untuk meningkatkan efisiensi dan efektivitas, transparansi dan akuntabilitas pemerintah dalam memberikan pelayanan publik secara lebih baik. Dalam pengembangan E-Government melalui E-Leadership membutuhkan kepemimpinan yang kuat di masing-masing institusi atau unit pemerintahan agar proses transformasi menuju E-Government dapat dilaksanakan dengan sebaik-baiknya.

Kepemimpinan dimaksud harus memiliki kemampuan untuk mengelola Sumber daya Manusia (SDM) pegawai, peralatan, dan sumber-sumber daya yang ada disetiap institusi secara bersama-sama melalui berbagai peran kepemimpinan dan pemanfaatan teknologi informasi untuk memecahkan permasalahan dan mencapai visi dan misi institusi yang telah ditetapkan. Kepemimpinan yang memiliki kompetensi semacam inilah yang lazim disebut dengan E-Leadership.

Menurut Nahrawi dalam Hardiansyah (2011:117) E-Leadership merupakan aspek ini berkaitan dengan prioritas dan inisiatif negara dalam mengantisipasi dan memanfaatkan kemajuan teknologi informasi. Dalam hal ini berkaitan dengan kepemimpinan dalam memadukan antara teknologi informasi dan kinerja pegawai sehingga dapat memberikan pengambilan keputusan yang lebih cepat dan efektif.

Berdasarkan hasil wawancara dan observasi ke lokasi penelitian. Bahwa E-Leadership yang sudah dikembangkan sudah baik dilakukan yang mana disebutkan E-Leadership merupakan suatu sistem pola kepemimpinan yang dilakukan melalui integritas antara makna E-Leadership kepemimpinan itu sendiri dengan teknologi informasi baik itu dalam konteks sistem kerja ataupun dalam konteks peningkatan produktivitas kerja 
dalam rangka pencapaian tujuan tertentu atau organisasi, sehingga dalam hal ini terdapat perpaduan antara teknologi informasi dengan proses pengambilan keputusan tentang kepemimpinan.

Penerapan e-leadership di badan kepegawaian dan pengembangan sumber daya manusia selama ini telah dituangkan untuk meningkatkan inovasi kinerja para pemimpin yang merupakan perwujudan dari penyatuan atau penggabungan dan kinerja harian pegawai dengan pemanfaatan teknologi informasi. Ada beberapa inovasi yang dilakuan dilakukan untuk mengembangan $e$ government yaitu salah satunya dengan adanya aplikasi SIMPEG tersebut.

Penerapan SIMPEG yang berbasis on line diterapkan sejak tahun 2013 sehingga sampai saat ini SIMPEG terus menerus melakukan perbaikan. Secara umum, SIMPEG dapat meningkatkan kualitas SDM dengan penyediaan informasi yang akurat dan efisien sehingga pengambilan keputusan dapat secara objektif dilakukan. Secara strategis, aplikasi SIMPEG merupakan salah satu sistem yang bergerak dibidang kepegawaian dan mampu menumbuhkan pengetahuan memelihara, memperkaya, dan menyediakan pengetahuan dibidang kepegawaian kepada pihak- pihak yang membutuhkan sebagai basis pengambilan keputusan yang akurat pada saat yang tepat.

Berdasarkan hasil wawancara dan observasi ke lokasi penelitian. Inisiatif yang dilakukan pemimpin sangatlah bagus, dalam hal ini inisitif yang dilakukan ada dua yaitu Top Down dan Bottom Up. Sehingga antara pimpinan dan bawahannya saling bekerja sama untuk mengantisipasi kendala tersebut yaitu selalu mengidentifikasi setiap kendala-kendala ataupun masalah yang dihadapi. Dengan adanya identifikasi itu secara berkelanjutan untuk mencoba mencari solusi.

Strategi yang dilakukan untuk mengantisipasi kendala tersebut dengan melakukan ritme-ritme kerja untuk mengantisipasi masalah yang sering terjadi khususnya di daerah kepulauan dan juga di daerah daratan yaitu dengan melakukan dua cara melalui pelayanan secara on-line dan off-line. Yang dimaksud dengan on-line yaitu layanan yang bisa dilakukan kapan saja melalui jaringan yang digunakan tetapi jika pelayanan dilakukan dengan off-line maka pelayanan yang dilakukan dengan melakukan pendampingan baik itu para pegawai mendatangi suatu OPD atau mereka yang berkonsultasi kepada kantor badan kepegawaian dan pengembangan sumber daya manusia.

\section{Infrastruktur Jaringan Informasi}

Penerapan E-government tidak terlepas dari sarana dan prasarana seperti infrastruktur jaringan informasi yang menjadi sarana penyediaan jaringan Internet terutama untuk melakukan pengelolaan data agar kualitas layanan lebih baik dan cepat. Menurut Winarno (2006:16.14) tentang tujuan pengembangan E-Government salah satunya meningkatkan kulitas layanan pemerintah kepada masyarakat, terutama dalam bidng konsistensi (tidak pandang bulu), kecepatan layanan, kepastian penyelesaian layanan, dan kecepatan pemprosesan data. Jika dikaitkan dengan hasil observasi dilapangan bahwa di badan kepegawaian dan pengembangan sumber daya manusia sudah memberikan pelayanan yang baik terutama dalam pengelolaan SIMPEG yang telah dilakukan secara on line yang sebelumnya dilakukan secara manual.

Menurut Wibawa (2009:99) tentanag tahap pengembangan E-Government terkait dengan tahap interaktif yaitu penggunaan teknologi internet memungkinkan kontak antara pemerintahan dan masyarakat melalui Situs web dapat dilakukan on line sehingga memungkinkan interaksi yang lebih intensif dan terbuka. Jika dikaitkan dengan observasi penelitian ini yang salah satu pengelolaan yang dilakukan secara on line yang dilakukan oleh badan kepegawaian dan pengembangan sumber daya manuisa dengan adanya penerapan SIMPG tersebut, infrastruktur jaringan informasi yang terdapat di BKPSDM ini sudah cukup sehingga terdapat interaksi yang dilakukan antara atasan dan bawahan agar tercipta hubungan yang lebih baik serta dengan melakukan pengelolaan secara on line maka akan memberikan transparansi kepada para pengawai yang ada di kabupaten sumenep untuk mengelola SIMPEG tersebut.

Menurut Nahrawi dalam Hardiansyah (2011:117) Infrastruktur Jaringan Informasi merupakan aspek yang berkaitan dengan kondisi infrastruktur telekomunikasi serta akses, kualitas, lingkup, dan biaya jasa akses. Jika dikaitkan dengan penerapan E-Government terutaman dalam penggunaan aplikasi SIMPEG ini sudah cukup baik.

Infrastruktur Jaringan Informasi untuk membangun atau menerapkan sebuah E-Government itu tidak bisa dilakukan hanya satu Organisasi perangkat daerah (OPD). Sehingga harus ada kerjasama yang dilakukan antara OPD lainya. Salah satu contohnya adalah penerapan sistem informasi manajemen kepegawaian yang mana yang menyediakan aplikasi ini adalah badan kepegawaian dan pengembangan sumber daya manusia, tetapi mengenai infrastruktur jaringan informasi dan koneksi internet di setiap OPD dikelolah oleh dinas komunikasi dan informatika.

Infrastruktur jaringan informasi yang dilakukan oleh badan kepegawaian dan pengembangan sumber daya manusia sampai saat ini terus melakukan upaya percepatan, jika terkait dengan infrastruktur maka setiap OPD memiliki infrastruktur yang bervariasi. Terkadang 
ada yang cepat dan ada juga yang lambat untuk mengakses internet. Pada saat ini masih dalam proses pemasangan instrument jaringan. Harapannya kedepan bisa membantu melakukan pemerataan jaringan dengan menggunakan strategi seperti pemasangan, melakukan observasi, melakukan evaluasi, dan selalu melakukan kolektif.

Berdasarkan observasi yang dilakukan terkait dengan infrastruktur jaringan informasi salah satunya yaitu bertujuan untuk menerapkan SIMPEG yang dilakukan secara on line sejak tahun 2013, infrastruktur jaringan informasi tiap tahun melakukan perbaikan. Sehingga semua OPD, kecamatan dan pengelolaan data kepegawaian lainnya dapat mengangsesnya. Sehingga infrastruktur jaringan informasi sudah disediakan seperti server besar dan fiber optic untuk mengelolah data-data pegawai di seluruh kabupaten sumenep. Dan terkait dnegan biaya yang dikeluarkan untuk mengakses aplikasi SIMPEG ini gratis karena tidak ada biaya yang dikeluarkan kecuali untuk biaya internet untuk bisa terus tersambung ke aplikasi SIMPEG ini.

\section{Pengelolaan Informasi}

Menurut Nahrawi dalam Hardiansyah (2011:117) Pengelolaan Informasi merupakan aspek yang berkaitan dengan kualitas dan keamanan pengelolaan informasi, mulai dari pembentukan, pengolahan, penyimpanan, sampai penyaluran dan distribusinya.

Pengelolaan informasi yang dilakukan sudah seesuai dengan standart pelayanan dengan cara selalu melakukan up datting jika terdapat perubahan terkait dengan data-data pegawai sedangkan kualitas pengelolaan informasi dapat dilihat dari penilaian yang dilakuakan di website bkpsdm.sumenepkab.go.id. Terdapat polling penilaian atas kualiatas pengelolaan informasi. Untuk itu terdapat transparansi penilaian yang dilakukan baik semua pegawai yang ada di kabupaten sumenep bahwa masyarakat juga dapat mengaksesnya dan menilai bagaimana kualitas pelayanan saat pengelolaan informasi.

Menurut Budi (2006:67) tentang keamanan teknologi jaringan komputer sangan dibutuhkan oleh organisasi dalam membangun sistem infomasi secara terintegrasi karena setiap jaringan komputer memberikan perlindungan terhadap data. Berdasarkan hasil wawancara dan observasi yang dilakukan jaminan keaman data tersebut diberikan melalui pengamatan data akses para pemakai dan password, serta teknik perlindungan terhadap hard disk sehingga data akan mendapatkan perlindungan yang efektif.

Berdasarkan keamanan untuk mengelolah informasi data kepegawaian terutama pengelolaan SIMPEG ini disana terdapat server yang sudah dikelola secara mandiri, artinya setiap OPD dapat mengelola data kepegawaian jika ada suatu perubahan data maka dapat secara langsung melakukan up datting data, sehingga tidak menoton ke satu pihak saja. Namun dalam hal ini untuk mengelolah data kepegawaian di kabupaten sumenep dikendalikan dan di control oleh Badan Kepegawain dan Pengembangan Sumber Daya Manusia.

Berdasarkan distribusi persebaran pengelolaan informasi sudah berjalan dengan baik artinya dalam mengaplikasikan suatu SIMPEG tersebut sudah difasilitasi oleh BKPSDM serta kerjasama yang dilakukan oleh dinas komunikasi dan informatika sebagai penyedia layanan internet. Aplikasi SIMPEG ini dapat dilakukan dimana saja terutama di daerah kepulauan disana telah disediakan satelit oleh DISKOMINFO. Terkait dengan sasaran dalam pengelolaan SIMPEG sudah terealisasi yaitu dengan menyediakan suatu informasi untuk melakukan secara cepat, tepat, akurat. Untuk menetapkan sasaran pendukungnya adalah mereka yang mempunyai relevansi hubungan khusus dengan penyediaan informasi dan seluruh OPD.

\section{Masyarakat dan Sumber Daya manusia}

Menurut Nahrawi dalam Hardiansyah (2011:117) Masyarakat dan Sumber Daya Manusia merupakan aspek ini berkaitan dengan difusi teknologi informasi didalam kegiatan masyarakat baik perorangan maupun organisasi, serta sejauh mana teknologi informasi disosialisasikan kepada masyarakat melalui proses pendidikan. Jika dikaitkan dengan penerapan SIMPEG di badan kepegawaian dan pengembangan sumber daya manusia bahwa sumber daya manusia yang terdapat disana cukup baik walaupun hanya 8 pegawai yang berada di bagian bidang data dan informasi.

Berdasarkan hasil wawancara dan observasi ke lokasi penelitian, menyatakan bahwa sumber daya manusia yang ada mempunyai tenaga-tenaga handal dibidangnya dengan jumlah personal yang ada pegawai terus berusaha untuk memberikan pelayanan terutama pada pelaksanaan SIMPEG tersebut. Namun jika dikaitkan dengan standart jumlah pegawai masih belum, tetapi dengan jumlah 8 personil pengelolaan data-data pegawai salah satunya untuk mengaplikasikan SIMPEG sudah cukup baik, karena mulai tahun 2013 penerapan SIMPEG ini dilakukan dengan berbasis on line sehingga tidak juga memerlukan terlalu banyak operator atau pengelola pegawai.

Berdasarkan hasil wawancara dan observasi ke pada salah satu operator yang mengelola kepegawaian terkait dengan jumlah pegawai yang terdapat di bidang data dan informasi masih kurang, hendaknya di tambah untuk bagian staff atau pelaksanan agar pengelolaan data kepegawaian dapat berjalan dengan efektif dan cepat. 
Sumber daya manusia yang terdapat di bidang data dan infomasi melakukan suatu inovasi yang dilakukan dengan mengadakan sosialisasi tentang penerapan kepada para operator atau pejabat pengelolaan data kepegawaian sekita 178 di kabupaten sumenep. Salah satu sosialisasi yang dilakukan tentang informasi melalui Web portal serta acara rekonsilisasi. Sosialisasi rutin ini dilakukan biasanya 2 kali dalam setahun, tetapi jika tidak rutin hamper setiap hari para operator berkunjung dan melakukan pendampingan terkait dengan kesulitan saat pengelolaan SIMPEG ini.

Berdasarkan hasil wawancara dan observasi ke lokasi penelitian BKPSDM sudah melakukan sosialisasi salah satunya mengenai penggunaan aplikasi SIMPEG Alhamdulillah sudah berjalan dengan bagus, karena sebelum menyampaikan kepada pihak luar para staff dilakukan home planning atau pelatihan terdahulu sebelum menyampakkan kepda para operator di tiap Pegawai yang berada di Kabupaten Sumenep. Semua pegawai di BKPSDM harus mengetahui pengamplikasikan SIMPEG terdahulu, untuk itu baru bisa melakukan sosialisasi kepada para operator kepegawaian dan juga kantor BKPSDM sangat membantu para operator jika terdapat kesulitan, pegawai disana sangat ramah saat melakukan pelayanan khususnya pengelolaan data kepegawaian. Terkadang para operator di setiap OPD ada kesulitan untuk ngakses perubahan data pegawai saat melakukan pelatihan atau pemberdayaan para pegawai disana sangat welcome dan terkadang juga para staff melakukan observasi atau pengecekan kepada tiap-tiap OPD untuk menanyakan apakah ada kendala atau kesulitan untuk proses peng up date tan data-data pegawai.

\section{PENUTUP}

\section{Simpulan}

Berdasarkan hasil penelitian, analisis, dam pembahasan yang telah dilakukan, dapat disimpulkan bahwa penerapan E-Government dalam pelayanan administrasi kepegawaian di badan kepegawai dan pengembangan sumber daya manusia kabupaten sumenep sudah cukup baik. Hal ini dibuktikan dengan pemanfaatan teknologi informasi yang ditinjau dari sejumlah aspek sesuai teori Nahrawi dalam hardiansyah (2011:117) yaitu:

1. E-leadership yang diterapkan sudah baik, dilihat dari pemanfaat teknologi Informasinya khususnya pengelolaan SIMPEG. E-Leadership merupakan Suatu sistem pola kepemimpinan yang dilakukan melalui integritas antara makna E-Leadership atau kepemimpinan itu sendiri dengan teknologi informasi baik itu dalam konteks sistem kerja ataupun dalam konteks peningkatan produktivitas kerja dalam rangka pencapaian tujuan tertentu atau organisasi dan mengenai proses pengambilan Keputusan. Inisiatif yang dilakukan sangatlah bagus, dalam hal ini inisitif yang dilakukan ada dua yaitu Top Down dan Bottom Up.

2. Infrastruktur jaringan informasi yang disediakan oleh badan kepegawaian dan pengembangan sumber daya manusia kabupaten sumenep sudah cukup baik, namun dalam menyediakan infrastruktur tidak terlepas dengan kerja sama setiap lembaga atau instansi salah satu yang menyediakan infrastruktur jaringan informasi adalah dinakomunikasi dan informatika sedangkan badan kepegawaian dan pengembangan sumber daya manusia hanya menyediakan aplikasi SIMPEG saja yang akan di kelola oleh lembaga, kecamatan dan lain sebagainya untuk mengelola data pegawai di seluruh wilayah kabupaten sumenep.

3. Pengelolaan informasi dalam penerapan SIMPEG ini sudah cukup baik dilihat dari kualitas pengelolaannya yang selalu melakukan up datting data, serta keamanan yang dilakukan selama ini sudah cukup baik yang disediakan server besar untuk penyimpanan data dan keamanan tentang pengelolaan data kepegawaian di kabupaten sumenep.

4. Masyarakat dan sumber daya manusia kaitannya dengan penerapan SIMPEG ini sebagai salah faktor keberhasilan dalam suatu organisasi, dengan adanya sumber daya manusia sebagai operator untuk menjalankan aplikasi SIMPEG disana cukup memadai, walaupun dengan jumlah pegawai yang ada di bagian bidang data dan informasi berjumlah 8 personil tetapi semangat dan motivasi yang diberikan oleh pimpinan kepada bawahan selalu berjalan dengan baik begitu pula sebaliknya. Adapun kegiatan rutin yang dilakukan untuk melakukan sosialisasi tentang penerapan SIMPEG di BKPSDM yng dilakukan 2 kali dalam setahun. Biasanya diselenggarakan pada awal bulan dan akhir bulan.

\section{Saran}

Saran-saran yang dapat peneliti sampaikan terkait dengan fokus yang dilakukan menurut pendapat Nahrawi dalam Hardiansyah (2011:177) diharapkan dapat terus mengembangkan dan memanfaatkan teknologi informasi agar saat pengelolaan data pegawai dapat berjalan secara cepat dan lebih akurat 


\section{DAFTAR PUSTAKA}

Andrianto, Waluyo. 2007. Manajemen Publik. Konsep, Aplikasi \& Implementasinya Dalam Pelaksanaan Otonomi Daerah. Bandung: Mandar Maju

A.S. Moenir. 2010. Manajemen Pelayanan Umum Di Indonesia. Jakarta: Bumi Aksara.

Hardiansyah. 2011. Kualitas Pelayanan Publik. Jogyakarta: Gava Medias

Jamaluddin Ahmad. 2015. Metode Penelitian Administrasi Publik Teori Dan Aplikasi. Yogyakarta: Gava Media

Pasolong, Harbani.2007.Teori Administrasi Publik. Bandung: Alfabeta.

Ratminto \& Atik. 2012. Manajemen Pelayanan. Yogyakarta: Pustaka Pelajar.

Sedarmayanti. 2013. Reformasi Administrasi Pubik, Reformasi Birokrasi, Dan Kepemimpinan Masa Depan (Mewujudkan Pelayanan Prima dan Kepemerintahan yang Baik). Bandung: PT. RefikaAditama.

Sugiyono, 2011, Metode Penelitian Kuantitatif Kualitatif R\&D.Bandung: Alfabeta.

Sugiyono. 2014. Metode Penelitian Kuantitatif Kualitatif. Bandung: Afabeta.

Suaedi, Falih,Dkk. 2010. Revitalisasi Administrasi Negara Reformasi Birokrasi dan E-Government. Yogyakarta: GrahaIlmu.

Susanto, Azhar. 2013. Sistem Informasi Manajemen. Bandung: Lingga Jaya.

Wibawa, Samodra. 2009. Administrasi Negara, isu-isu kontemporer. Yogyakarta: Graha Ilmu

Winarno, Wing Wahyu. 2006. Sistem Informasi Akuntansi. Yogyakarta: UPP STIM YKPN Yogyakarta

Instruksi Presiden Republik Indonesia Nomor 3 Tahun 2003 Tentang Kebijakan dan Strategi Nasional Pengembangan E-Government dalam Motivasi Kebijakan E-Government pada Lampiran 1.

Keputusan Menteri Dalam Negeri Nomor 17 tahun 2000 Tentang Sistem Informasi Manajemen Kepegawaian. Departemen Dalam Negeri dan Pemerintah Daerah Pasal 3 (Ayat 3) Tentang SIMPEG Kabupaten/Kota Berkedudukan di Kabupaten/Kota. (Hal: 4) 